\title{
Late Holocene vegetation and fire dynamics on the summits of the Guayana Highlands: the Uei-tepui palynological record
}

Elisabet Safont ${ }^{\mathrm{a}}$, Valentí Rull ${ }^{\mathrm{b}}$, Teresa Vegas-Vilarrúbia ${ }^{\mathrm{a}, \mathrm{c}}$, Encarni Montoya ${ }^{\mathrm{b}}$, Otto Huber $^{\mathrm{d}}$, Bruce K. Holst ${ }^{\mathrm{e}}$

\footnotetext{
${ }^{a}$ Department of Ecology, University of Barcelona, Av. Diagonal 643, 08028 Barcelona, Spain.

${ }^{\mathrm{b}}$ Institute of Earth Sciences Jaume Almera (ICTJA-CSIC), C/ Lluís Solé i Sabarís s/n, 08028 Barcelona, Spain.

${ }^{c}$ Catalan Institute of Paleontology Miquel Crusafont (ICP), C/ de les columnes s/n, 08193 Cerdanyola del Vallès, Spain.

${ }^{\mathrm{d}}$ Experimental Institute Botanical Garden Dr. Tobías Lasser, Av. Salvador Allende, 1053 Caracas, Venezuela.

${ }^{\mathrm{e}}$ Marie Selby Botanical Gardens, 811 South Palm Avenue, Sarasota, Florida 34236, U.S.A.
}

Corresponding author: Elisabet Safont. E-mail: esafont@ub.edu. Telephone: +34 934031190. Fax: +34 934111438.

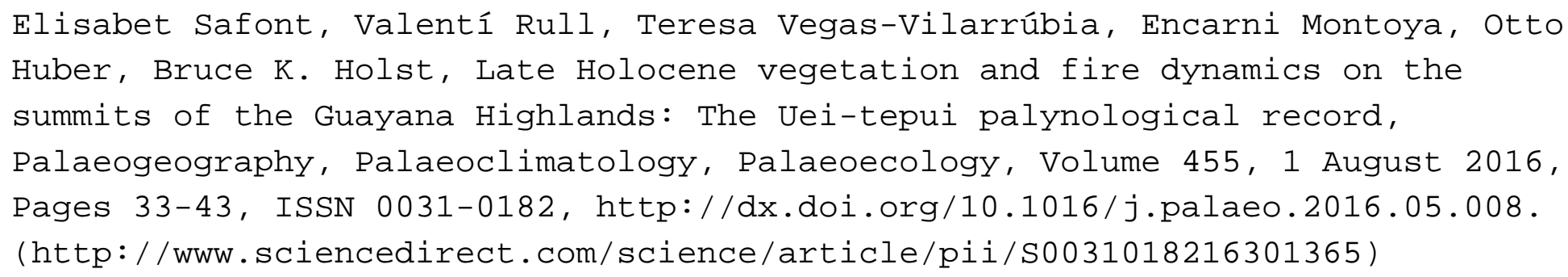




\begin{abstract}
The summits of the tepuis (sandstone table mountains of the Neotropical Guayana region - Guayana Highlands, GH) have been considered valuable for palaeoecological studies due to their pristine nature, which emphasizes the role of natural (i.e. nonhuman) factors on ecological change. Anthropogenic fires, very frequent in the surrounding Gran Sabana (GS) uplands, have been documented in the GH very rarely, and are therefore not considered an important ecological factor in the high-tepui biome. This paper reports the palynological and charcoal results of a late Holocene sequence from the summit of Uei-tepui (2104 m elevation), where extensive signs of fire were recently observed. Since 2000 cal yr BP the landscape of the study site has been dominated by meadows with occasional shrubs and cloud forests, which underwent expansions and contractions driven by climate changes and fire. A major vegetation shift occurred in the mid-18th century, when a sustained increase in local fires favoured the expansion of the low and spreading Cyrilla racemiflora shrublands at the expense of meadows and forests. Uei-tepui fires most probably were the result of human activities and reached the summit under study from the GS uplands through the vegetated slopes that characterize this tepui. The mostly anthropogenic nature of these fires, especially the more recent ones, is supported by the initial occurrence of wetter conditions, and by its coincidence with significant social changes in the GS indigenous populations, mainly the European contact. The emergence of fire as a disturbing agent of the $\mathrm{GH}$ biome highlights the need for an effective management plan in the GS uplands, where the vast majority of present-day fires originate, and designed in collaboration with the indigenous communities. Proactive conservation measures are considered even more important under future warming projections in the area.
\end{abstract}

Keywords: conservation; indigenous populations; Neotropics; palaeoecology; tepui; Venezuela. 


\section{INTRODUCTION}

The Guayana Highlands (GH) constitute a unique discontinuous biogeographic province (Pantepui), located within the neotropical Guayana Shield of northern South America (Fig. 1). It is composed of the summits of $\sim 50$ remote and almost inaccessible table mountains (1500-3014 m elevation), called tepuis (Huber 1995a). The tepui summits contain exceptional vascular plant diversity and endemism (>2400 known species, 30\% of which are GH endemics), which has lasted in an almost pristine state of conservation to our days (Nogué et al. 2009a; Safont et al. 2012; Steyermark et al. 1995-2005). This unusual conservation state makes them exceptional environments to test hypothesis about climatic forcing, and the corresponding ecosystem responses (Rull 2005a). In addition, the GH have been considered a natural laboratory to study relevant ecological, biogeographic, and evolutionary aspects of the neotropical biota (Rull 2010; Rull et al. 2013). Recent studies suggest that upward displacements of summit taxa due to the global warming can result in the extinction of a number of plant species owing to total habitat loss (Nogué et al. 2009a; Rull and Vegas-Vilarrúbia 2006; Safont et al. 2012). In this regard, palaeoecological studies may provide valuable information on the responses of the GH biota to past environmental changes, thus offering more reliable criteria for improving biodiversity conservation strategies in face of the projected global warming.

The palaeoecological information available thus far for the $\mathrm{GH}$ is relatively recent and refers to the middle and late Holocene. The lack of Pleistocene sediments (prior to 11.7 kyr BP) in the first palaeoecological surveys was related to purported extended aridity in the entire Guayana region during the last glacial period (Schubert and Fritz 1985; Schubert et al. 1986). However, subsequent studies conducted at lowland localities documented temperature and moisture changes during the Last Glacial Maximum and across the Pleistocene/Holocene boundary (Bush et al. 2004; Montoya et al. 2011a; Rull 2007). In addition, the aridity hypothesis was based on relatively few sampling points in the total GH area $\left(\sim 6000 \mathrm{~km}^{2}\right)$. In the last decade, a number of palaeoecological studies have been conducted in the tepui summits, mainly located at the Chimantá Massif (eight records, between 1950 to 2627 m elevation), and two at the Guaiquinima Massif (1350 m elevation) (Fig. 1). In the Chimantá Massif, the Acopán, Amurí, and Toronó tepuis showed relative vegetation stability over the last 6 cal kyr BP, with only minor local reorganizations between Stegolepis meadows and Bonnetia gallery forests. These reorganizations were most likely caused by changes in local moisture conditions, due to 
the lateral shifting of water currents along the extensive alluvial plains of the Chimantá Massif (Rull 2005a). The highest tepui of this massif, Eruoda-tepui, also showed vegetation stability over the last 4 cal kyr BP (Nogué et al. 2009b). This ecological stability was explained in terms of either climatic stability, insensitivity of vegetation at the coring sites to climatic shifts, or climatic buffering atop the tepuis due to perhumid conditions (Rull 2005a). Moreover, the long-term vegetation stability was used as an example to discuss the concept of potential natural vegetation in the Neotropics (Rull 2015). This concept was considered by Rull (2015) as 'unnecessary' given the difficulty to differentiate some of these records from other transient ecological states, their scarcity in the palaeoecological literature in comparison to those exhibiting continuous environmental and ecological change, and their restriction to particular environments. In other tepuis, however, some significant vegetation changes were related to climatic changes. For example, in the Churí-tepui, the replacement of Chimantaea shrublands by Stegolepis meadows at $3.5 \mathrm{cal}$ kyr BP was explained as an upward displacement of the altitudinal ecotone between these communities, likely driven by a regional shift to warmer and wetter conditions (Rull 2004a,b,c). The Apakará-tepui record showed a significant vegetation change around $5.3 \mathrm{cal} \mathrm{kyr} \mathrm{BP}$, as a consequence of a shift from warmer and wetter climates (coinciding with most neotropical records and the Northern Hemisphere Holocene Thermal Maximum (Renssen et al. 2009)), to cooler and drier conditions, similar to present (Rull et al. 2011). Finally, successive replacements of Stegolepis meadows, Archytaea gallery forests, and upland forests were recorded in the Guaiquinima Massif during the last $8.4 \mathrm{cal}$ kyr BP, which were attributed to moisture changes, probably of regional extent (Rull 2005b).

In the GH palaeo-records, climate seems to have been the main driver of conspicuous vegetation changes on the tepui summits, as no any evidence of human disturbance has been recorded during the Holocene. The indigenous inhabiting the surrounding Gran Sabana (GS) uplands nowadays, called Pemón, consider the tepui summits as the home of gods or the remains of their tree of life, and thus sacred lands forbidden to humans (Gorzula and Huber 1992). Only a few tepui summits are routinely visited for touristic reasons, namely Roraima and Auyán. Contrastingly, the GS, characterized by a plateau with extensive savannas from where the tepuis rise (Fig. 2), has been affected by the regular action of fires since the Lateglacial (ca. 13 cal kyr BP), with a remarkable exacerbation during the last 2000 years (Montoya and Rull 2011; Montoya et al. 2011a; 
Rull et al. 2013, 2015a). At present, it is estimated that more than ca. 10,000 fires are lit every year by humans in the GS but there is little evidence of burning, intentional or not, atop the tepuis (Huber 1995b). The eventual occurrence of Holocene fires in the tepui summits would significantly change the current conception of their ecological development. One of the more conspicuous records of a fire event of unknown age was observed recently at the top of the Uei-tepui (2150 m elevation), of the Eastern Tepui Chain (ETC). This fire likely reached the Uei summit from the GS uplands (ca. $1000 \mathrm{~m}$ elevation) due to the gradual slopes and herbaceous vegetation cover continuity that characterize the southern and western faces of this tepui. The present vegetation of the Uei-tepui summit shows clear and extensive signs of burning, indicating that presentday vegetation is likely the result of secondary regrowth after fire (Fig. 3). This provides a unique opportunity for the study of the ecological effects of fire on tepuian flora and vegetation, a process that has not been documented previously in the $\mathrm{GH}$ and opens a new dimension in the study of vegetation dynamics atop the tepuis.

In this paper, we report the results of pollen and charcoal analysis of a peat core obtained in the summit of Uei-tepui, spanning from 2 cal kyr BP to the present. The main aims are to: 1) record the vegetation changes that occurred in the Uei summit during the late Holocene, 2) investigate the potential relationship of these vegetation changes with eventual climatic shifts and fire events, 3) date the fire event mentioned above and assess its role in the shaping of present vegetation, and 4) evaluate the implications of the results for the conservation of the tepui ecosystems. For this study, we have selected the last 2000 years because this time period has been crucial for the shaping of present-day vegetation cover under the influence of both climatic and anthropogenic drivers, not only in the Guayana region but also in the Neotropics (Flantua et al. 2016; Montoya and Rull 2011; Rull et al. 2013; Rull and Montoya 2014). The last 2000 years are known to be decisive worldwide to understand the climatic and ecological dynamics useful to simulate potential future warming scenarios. The development of palaeoecological studies embracing this time period is urgently needed, especially in the tropics, where records of the past are still comparatively scarce (Flantua et al. 2015, 2016). 


\section{STUDY AREA}

- Guayana Highlands (GH)

The GH are a complex of table mountains as the remnants of former erosion surfaces with localized diabase intrusions, developed on the sandstone and quartzites of the Roraima Group, belonging to the Precambrian Guayana Shield (Briceño and Schubert 1990). The climate in the upper slopes and in most GH summits situated between 1500 and $2400 \mathrm{~m}$ elevation is mesothermic ombrophilous, with average annual air temperature of 12 to $18{ }^{\circ} \mathrm{C}$ and average rainfall of 2500 to $3500 \mathrm{~mm}$ per year, whereas the highest summits (>2500 m) are characterized by submicrothermic ombrophilous climate conditions, that is, up to $10{ }^{\circ} \mathrm{C}$ of average annual air temperature and heavy rainfall, with low seasonality -a true dry season is virtually absent (Huber 1995a). The frequent occurrence of dense mists supplies additional moisture to the vegetation.

The vegetation of the GH summits has been classified into four main physiognomic types (Huber 1995c): 1) low evergreen forests, 2) tepuian shrublands, 3) high-mountain meadows and grasslands, and 4) pioneer vegetation. Forests are characterized by a very high frequency of orographic mist during much of the year (cloud forests) and, in the ETC, are usually dominated by Bonnetia tepuiensis and B. roraimae (Bonnetiaceae). Other important trees are Podocarpus spp. (Podocarpaceae), Magnolia ptaritepuiana (Magnoliaceae), Schefflera spp. (Araliaceae), and Weinmannia spp. (Cunoniaceae). Most of these forests are densely covered by lichens, mosses, ferns, and other epiphytes. The understory is also dense, and Orectanthe ptaritepuiana (Xyridaceae), Brocchinia tatei (Bromeliaceae), Didymiandrum stellatum (Cyperaceae), and bambusoid grasses (Myriocladus spp.) are frequent. The shrublands are probably the most diverse plant formations on tepuian ecosystems, the more emblematic being the paramoid shrublands dominated by several endemic species of Chimantaea (Asteraceae) on the summits of the Chimantá Massif between 1900 and 2600 m elevation (Huber 1992a).

Non-gramineous meadows are also characteristic of the GH vegetation and their floristic composition and physiognomic structure vary considerably from one massif to another. Four types have been recognized: 1) broad-leaved meadows, typically dominated by various species of Rapateaceae, especially of the genus Stegolepis, 2) tubiform meadows, dominated by tubiform herbs of Bromeliaceae (typically Brocchinia) or Sarraceniaceae (Heliamphora), 3) rosette meadows, characterized by 
dense rosette herbs of Xyridaceae and Eriocaulaceae, and 4) fruticose meadows, where the herbaceous layer is mixed with abundant low shrubs. In most tepui summits of the ETC (between 2400 and 2750 m elevation), rosette meadows are dominated by Orectanthe sceptrum (Xyridaceae), Connellia augustae, and C. quelchii (Bromeliaceae), and many species of Eriocaulaceae. On the lower summits of the ETC (2000-2400 m elevation), rosette meadows are mainly composed of large colonies of Brocchinia tatei, accompanied by Neurolepis angusta (Poaceae, Bambusoideae), Heliamphora heterodoxa, Orectanthe sceptrum, Xyris spp. (Xyridaceae), many species of Eriocaulaceae, and Everardia spp. (Cyperaceae). Grasslands are restricted to sites with particular local conditions. For example, Cortaderia roraimensis (Poaceae) can form dense and almost monospecific colonies on periodically flooded soils or peats near water courses. Aulonemia spp. (Poaceae, Bambusoideae), Cladium costatum, and Rhynchocladium steyermarkii (Cyperaceae) occur occasionally in these plots. Pioneer communities occur on rocky substrates, which are especially abundant on the high summits of the ETC (Roraima, Kukenán, Yuruaní, Ilú, and Tramen). Most colonizers of these highland rock outcrops are algae, fungi and lichens, as well as several Bromeliaceae, such as Lindmania, and Brocchinia (Huber 1995c).

- Uei-tepui summit

The Uei-tepui (maximum elevation $2150 \mathrm{~m}$ ) is located in the eastern district of the $\mathrm{GH}$ along the border with Brazil, $20 \mathrm{~km} \mathrm{SE}$ of the southern cliffs of Roraima-tepui (Fig. 1). Uei is the southernmost tepui of the ETC, which comprises 11 mostly open and rocky tepui summits. In contrast to other ETC tepui summits, which are mostly surrounded by vertical cliffs, Uei-tepui has gradual slopes enabling the topographic continuity between its summit and the GS savannas to the $\mathrm{S}$ and $\mathrm{W}$, and dense rainforests to the $\mathrm{N}$ and $\mathrm{E}$ (Fig. 2) (Huber 1995a). The coring site of this work was in a peat bog located in the summit, at $\sim 1.35 \mathrm{~km} \mathrm{~N}-\mathrm{NE}$ of the peak. The present vegetation of the site is relatively complex, with herbaceous meadows as the dominant vegetation element, alternating locally with shrublands, and dwarf forest stands of Bonnetia tepuiensis (Fig. 3). During the fieldwork of this study in February 2007, the frequent occurrence of clusters of standing charred trees, probably a species of Bonnetia, was considered evidence of former widespread tepuian cloud forests, and the significant reduction of this forest cover caused by an extensive fire event of unknown age. Therefore, the dominant broad-leaved meadows were considered as secondary vegetation. The herbaceous 
component is dominated by broad-leaved plants, notably large clumps of Stegolepis guianensis, Xyris spp., Eriocaulaceae, Lycopodiella sp. (Lycopodiaceae), and large rosettes of Brocchinia tatei and Connellia augustae. In the more humid areas, meadows are characterized by a higher frequency of B. tatei and large colonies of Heliamphora sp. with tubular leafs of $50 \mathrm{~cm}$ or more in height. Two types of shrubby formations have been distinguished in the Uei-tepui summit. One is dominated by Phyllanthus pycnophyllus (Euphorbiaceae), with Gaiadendron punctatum (Loranthaceae), Cyrilla racemiflora (Cyrillaceae), Meriania crassiramis (Melastomataceae), Cybianthus sp. (Myrsinaceae), and the liana Passiflora sclerophylla (Passifloraceae). The other is more restricted and characterized by tall $(3-5 \mathrm{~m})$ shrubs such as Poecilandra retusa (Ochnaceae), Coccoloba schomburgkii (Polygonaceae), and M. crassiramis. The level of botanical exploration of Uei-tepui is relatively low in comparison with other tepuis. The species recorded for its summit through herbarium specimens are provided in Online Resource. Uei-tepui is included in the Venezuelan Cadena de Tepuyes Orientales Natural Monument, which includes six tepuis of the ETC (Huber 1995b).

\section{METHODS}

- Coring site

A $185 \mathrm{~cm}$ peat core (PATAM8 A07; 5.01604N, 60.61449W, 2104 m elevation), consisting of four drives of $5 \mathrm{~cm}$ diameter and $50 \mathrm{~cm}$ maximum length each, was obtained using a Russian corer (Jowsey 1966). The whole section was composed of black peat, showing granular structure from the base to $100 \mathrm{~cm}$ depth, and fibrous texture from this depth to the surface (Fig. 4). The core was sampled in the field at 2 $\mathrm{cm}$-depth intervals (except for the uppermost $8 \mathrm{~cm}$, where only two samples could be retrieved at 0-5 and 5-8 cm), for a total of 91 samples. In this study, the upper 46 samples were analysed, corresponding to the last $2000 \mathrm{cal}$ yr BP. A surface sample of peat was taken in the same coring site (consisting of broad-leaved meadow, mainly Stegolepis guianensis, Brocchinia tatei and Cyrilla racemiflora) for comparison.

- Sampling processing, identification, and counting

Sediment samples of 2.8 to $3.1 \mathrm{~g}$ were used for chemical processing, after adding Lycopodium clavatum spore tablets (batches 177,745 and 1031, average 18,584 \pm 1853 
and 20,848 \pm 3457 spores per tablet, respectively). Given that this species is present on the summit of the Roraima-tepui (Safont et al. 2014) a test with four samples was conducted without the addition of the tablets to verify that it was not present in the Ueitepui sediment. The standard pollen processing protocol was followed, including $\mathrm{KOH}$, $\mathrm{HCl}$, and HF digestions, and acetolysis (Bennett and Willis 2001). Slides were mounted in silicone oil after dehydration and sealed with nail polish. Pollen and spore identifications followed Burn and Mayle (2008), Contreras-Duarte et al. (2006), Leal et al. (2011), López-Martínez et al. (2010), Murillo and Bless (1974; 1978), Rull (1998; 2003), and Salgado-Laboriau and Villar (1992), as well as more general literature (Bauermann et al. 2013; Colinvaux et al. 1999; Herrera and Urrego 1996; Roubik and Moreno 1991; Tryon and Lugardon 1991), and the Neotropical Pollen Database (Bush and Weng 2006).

For each sample, counting was conducted until a minimum of 300 pollen grains from terrestrial vegetation and pteridophyte spores (including a minimum pollen sum of 200), though counts were usually higher because they were continued until the diversity did not change significantly any more (Rull 1987). The average pollen sum was 324 (ranging from 271 to 519), which includes all pollen types except azonal aquatics (Sagittaria, Alismataceae, and Isoetes, Isoetaceae) and excludes pteridophyte spores. Microcharcoal particles were counted from the same palynological slides and were subdivided into three size classes (modified from Rull 1999): Type I) 5-100 $\mu \mathrm{m}$, as a proxy for mostly regional fires because of their easy dispersion by wind; Type II) 100$500 \mu \mathrm{m}$, as a proxy for local fires; and Type III) $>500 \mu \mathrm{m}$, as a proxy for high virulence local fire events, and represented as presence/absence.

\section{- Diagram and interpretation}

The pollen diagram was plotted and zoned with Psimpoll version 4.27, based on pollen types over $1 \%$ of abundance. Zonation was carried out after Optimal Splitting by Information Content, and their significance was tested with the broken-stick model (Bennett 1996). Pollen grouping according to ecological preference followed Huber (1992a,b; 1995c) and the Flora of the Venezuelan Guayana (Steyermark et al. 19952005), which was also the taxonomic reference. Accelerator mass spectrometry radiocarbon dating was carried out at the W.M. Keck Carbon Cycle AMS Laboratory (University of California) and Beta Analytic, on four samples consisting of plant 
macroremains found along the entire length of the sequence. In order to date the above mentioned fire event, an additional sample was taken in the most external part of a burnt tree trunk, rooted and in a natural growth position, and close to the coring site. Age calibration and the age-depth model were performed with clam.R (Blaauw 2010), using CALIB 7.0.0 and the IntCall3 database (Reimer et al. 2013). The interpretation of pollen spectra was based on the known ecological requirements of the taxa involved (Marchant et al. 2002; Rull 2003; Steyermark et al. 1995-2005), as well as the modern analogue studies available for the tepui summits (Rull 2005a). The differences between modern (surface) and core samples were measured through a dissimilarity analysis applying the Chord distance, a modification of the Euclidean distance to deal with the double-zero problem in species abundance data (Legendre and Legendre 2012), using only taxa included in the pollen sum.

\section{RESULTS AND INTERPRETATION}

\section{- Dating and age-depth model}

The four radiocarbon dates obtained ranged from 5200 to $220{ }^{14} \mathrm{C}$ yr BP ( 5954 to 228 cal yr BP) (Table 1). The best fit was obtained with a spline smooth age-depth model (Fig. 4). Average peat accumulation rates showed a gradual increase from $0.03 \mathrm{~cm} / \mathrm{yr}$ (phase I) to $0.10 \mathrm{~cm} / \mathrm{yr}$ (phase II) before and after $490 \mathrm{cal}$ yr BP (48 cm core depth), respectively. According to these results, the resolution of the pollen record is multidecadal to centennial, with ranges from 64 years per sampling interval $(y / s i)$ in phase I to $23 \mathrm{y} / \mathrm{si}$ in phase II. The age of the charred wood is most likely between 220 and 168 cal yr BP, with a Relative Area under the Probability Distribution (RAPD) of 0.547 (Table 1, Fig. 5). Other possible intervals are 282-262 cal yr BP (0.168), 153-141 cal yr BP (0.104), and 24-2 cal yr BP (0.180).

\section{- Vegetation trends}

The percentage diagram (Fig. 5) is primarily dominated by herbs and type-I $(5-100 \mu \mathrm{m})$ charcoal particles, except for the last $~ 300$ years, when forest species and the shrub Cyrilla racemiflora dominate the pollen assemblages, coinciding with an increase of type-II $(100-500 \mu \mathrm{m})$ and the appearance of type-III $(>500 \mu \mathrm{m})$ charcoal particles. The pollen concentration gradually increases with depth, showing a peak at $61 \mathrm{~cm}(\sim 810 \mathrm{cal}$ 
yr BP). The sequence has been subdivided into four significant zones, designated as Uei-I to Uei-IV. The following section provides the results and the interpretation of these zones:

Uei-I (96-64 cm, 2008-895 cal yr BP). This zone is characterized by the dominance of herbs, especially Xyris, followed by Cyperaceae, Poaceae, and Bromeliaceae. Shrubs are less abundant, being Biophytum the most relevant. Weinmannia, Cyrilla racemiflora, Miconia-type, Sauvagesia-type, and Ericaceae are also present but in low proportions. The main forest elements are Bonnetia, Doliocarpus (a liana), and Urticales, with Schefflera being poorly represented. The aquatic plant Sagittaria is also present and Lycopodiella is the most notable spore-bearing vascular plant in this zone. Type-I charcoal particles are present at intermediate values, indicating the existence of regional fires in the area. The pollen assemblages of this zone have intermediate dissimilarity values with the modern sample (Fig. 5), and suggest that the vegetation was dominated by open meadows, in which the shrub Biophytum was significantly more abundant than today, with patches of Bonnetia forests. The meadows were likely more humid than today, as suggested by the abundance of Xyris and the presence of Sagittaria, and the forest stands were more extended than the present ones. The abundance of Urticales (ca. 5-10\%) might suggest that they were important components of the Uei forests. However, the pollen grains of this order are dispersed by wind over long distances and percentages over $40 \%$ are required to infer their in situ occurrence (Gosling et al. 2009). Today, Urticales are not a component of the Uei-tepui summit vegetation; instead, they are abundant at the GS uplands (Steyermark et al. 1995-2005). Therefore, the presence of Urticales pollen grains in the Uei record is interpreted as likely transported from the GS uplands.

Uei-II (64-36 cm, 895-271 cal yr BP). This zone is characterized by a decrease in some woody elements, namely Bonnetia, Doliocarpus, and Biophytum, together with an increase of some herbs, mainly Cyperaceae, Poaceae, and Stegolepis guianensis. The similarity of this zone with the modern assemblage is higher (lower Chord distance) than in zone Uei-I. The coincidence with a prominent peak in type-I charcoal and the appearance of type-II at the beginning of the zone ( $\sim 810$ cal yr BP) suggests that a significant fire event reduced the forest cover and the woody elements of the meadows, allowing herbaceous taxa to increase their cover. The recovery of trees and shrubs after the initial decline was very slow and these elements did not reach their former values 
until the upper part of the zone ( $390 \mathrm{cal} \mathrm{yr} \mathrm{BP})$. This suggests a time period of nearly 400 years for Bonnetia cloud forests to recover after a fire event that affected the summit tepuian vegetation but did not involve the complete disappearance of the local community. Contrastingly, Biophytum did not recover its previous abundance after the fire and remained virtually absent after ca. $500 \mathrm{cal}$ yr BP. The disappearance of this species occurred at the middle of the zone, without any change in fire incidence; therefore, other environmental drivers may be involved. The same is true for the undetermined pollen type " $3-4 \mathrm{CP}$ psilate", suggesting that these two taxa might have similar habitat requirements that were no longer available from the middle of this period. In addition, the charcoal peak was synchronous with an increase in pollen concentration, especially of Urticales, Cyperaceae and Xyris. However, an interpretation of this coincidence would still be too premature and hypothetical, as modern analogue studies addressing the effects of fire on different taxa in the GH are non-existent.

Uei-III (36-16 cm, 271-49 cal yr BP). This zone is characterized by a remarkable increase of Bonnetia and Doliocarpus, which attained their maximum at the middle of the zone $(23-25 \mathrm{~cm}, \sim 131-111 \mathrm{cal}$ yr BP), coupled with the progressive but significant decrease of all herbaceous taxa. Also relevant is Cyrilla racemiflora, which shows a remarkable increase from $5 \%$ to $20 \%$ in the upper half of the zone. This is the zone of maximum dissimilarity with the modern assemblage, especially in its middle part. These trends coincide with a continued increase in charcoal. This zone can be interpreted in terms of a full recovery and further expansion of Bonnetia forests likely covering most of the summit area studied, as suggested by pollen percentages between $20 \%$ and $30 \%$, which indicate the local occurrence of dense tepuian cloud forests (Rull 2005a). An increase in local fires (type-II charcoal particles) could have been the responsible factor for the decline of herbaceous vegetation recorded since the beginning of the zone but may have not been enough to reduce the Bonnetia forest until the middle of the zone, possibly because of the existence of a humid microclimate inside the forest that prevented fire penetration (Chen et al. 1999). Once again, forest reduction was not catastrophic, as their main components (Bonnetia and Doliocarpus) declined gradually. The spread of Cyrilla racemiflora after fire was probably favoured by the removal of existing vegetation, given that this species is a well-known early colonizer of burnt areas due to its ability to develop vegetative sprouting from adventitious buds on the 
roots following fire disturbance (Coladonato 1992; Duever and Riopelle 1983; Ewel 1990; Kologiski 1977).

Uei-IV (16-0 cm, 49 cal yr BP-AD 2007). This zone is totally dominated by Cyrilla racemiflora (25-60\%), whereas Bonnetia and Doliocarpus show a significant but gradual decrease until reaching values similar to today. All herbaceous taxa are already at their minima at the beginning of the zone and did not undergo any significant change, which is also true for aquatic plants and ferns. All charcoal types attain a maximum at the beginning of the zone $(11-15 \mathrm{~cm}, 41-11 \mathrm{cal} \mathrm{yr} \mathrm{BP})$. The more likely interpretation is the continued reduction of forests and meadows due to local and intense fires, thus fostering the expansion of an aggressive colonizer such as Cyrilla racemiflora, which probably covered most of the summit area by the mid-late 20th century. Noteworthy, $C$. racemiflora did not stop to increase even after the fire maximum, possibly because its rapid growing once it has outcompeted the remaining species and has been successfully established (Robertson et al. 1998).

Since those times ( AD 1995, mean age of the upper core sample) to the present (AD 2007 , represented by the surface sample), a reduction of all taxa except most herbaceous elements has occurred, which is consistent with the present-day dominance of broadleaved meadows (Fig. 3). Neither Bonnetia forests nor Biophytum shrubs have recovered, on the contrary, they are even more reduced than the inferred abundances for the mid-late 20th century. The same is true for Cyrilla racemiflora, which cover has declined in favour of meadow expansion. Despite these changes in abundances, zone Uei-IV is the zone of maximum similarity (minimum Chord distance) with the surface sample assemblage. Modern charcoal values are intermediate and are largely dominated by type-I charcoal, suggesting regional fires, likely burning in the GS uplands. When compared with present-day vegetation, Xyris, Stegolepis guianensis, Poaceae, Cyrilla racemiflora, and Bonnetia are properly represented in the modern pollen assemblage, but Miconia-type, Ilex (not present in the diagram), Urticales, Doliocarpus, and Cyperaceae appear to be overrepresented in the surface sample. However, despite the frequent occurrence of large rosettes of Brocchinia tatei and Connellia augustae around the sampling site, these taxa are scarcely represented in the pollen assemblage. Eriocaulaceae, and all components of local shrubland vegetation (except Cyrilla and Cybianthus), are absent from the modern pollen assemblage. 


\section{DISCUSSION}

- Forcing factors of vegetation change

In this section, we compare the vegetation shifts deduced from the pollen record with the main climatic and anthropogenic drivers potentially involved. In the absence of palaeoclimatic reconstructions for the region under study, we use the marine Cariaco record (see location in Fig. 1), especially the Titanium record, which has been used as proxy for regional moisture variations during the Lateglacial and the Holocene. Ti values are correlated directly to the amount of terrigenous sedimentary input to coastal environments and, hence, are positively correlated with regional precipitation. In turn, precipitation patterns are dependent on the position of the Intertropical Convergence Zone (ITCZ). At $10^{\circ} \mathrm{N}$, the Cariaco basin sits at the northern edge of the annual latitudinal range of the ITCZ. During the summer, with the ITCZ nearly overhead, precipitation increases in regions that drain directly into the Cariaco basin or contribute to flow in the Orinoco River (Hastenrath and Greishar 1993), whereas during winter/spring, the ITCZ is located over the equator or further south, thus reducing precipitation over northern South America (Haug et al. 2001). Therefore, high Ti concentrations in the Cariaco record associated to wetter Holocene phases (Holocene Thermal Maximum, 10.5-5.4 cal kyr BP) indicate a more northerly mean annual position for the ITCZ relative to drier intervals (the later Holocene, from $\sim 3.8 \mathrm{cal} \mathrm{kyr}$ BP) (Haug et al. 2001). In the GS region, moisture variations and fire incidence -a combination of frequency and intensity- have been considered the more important environmental drivers of Holocene vegetation changes (Flantua et al. 2016; Rull et al. 2013).

During the period 2000-1050 cal yr BP, regional precipitation showed relatively high to intermediate values compared to the last 2000 years, coinciding with relative vegetation stability and the occurrence of regional fires. From 1050 to $900 \mathrm{cal}$ yr BP, an increase in precipitation (up to the maximum of the record), coeval with the beginning of the Medieval Climatic Anomaly (MCA, 1050-700 cal yr BP, Haug et al. 2001) (Fig. 6), did not result into major vegetation or charcoal changes, which suggests that regional climate may not have a straightforward relationship with fire incidence and vegetation trends. In fact, besides climatic conditions, the accumulation of biomass and ignition mechanisms are key in determining the occurrence of fire events. In this regard, the first 
significant shift observed in the pollen record is the decrease in woody species after the fire event occurred at $\sim 810$ cal yr BP, which coincided with a decrease of regional precipitation during the latter MCA (900-700 cal yr BP). The lower precipitation regime might have facilitated the generation of environmental conditions suitable for the occurrence of fires, although, as mentioned, biomass accumulation and ignition may have also been indispensable. The absence of local fires in the Uei summit in other periods of even lower precipitation may be thus due to the absence of at least one of these two factors.

Shortly after $\sim 670$ cal yr BP regional precipitation increased remarkably. This shift towards wetter climatic conditions was synchronous with a reduction of fire incidence, which was maintained even when precipitation decreased to the minimum of the record during the Little Ice Age (LIA, 500-175 cal yr BP, Haug et al. 2011) (Fig. 6), thus favouring forest recovery. Rull (1999) also recorded lower fire incidence between 600 and 200 cal yr BP in Urué, a GS locality at $~ 70 \mathrm{~km}$ east of Uei-tepui, coinciding with the lowest charcoal concentration of this study. Remarkably, the Ti record from Cariaco represents a notable exception to the regional picture of wetter LIA conditions in northern South America, possibly explained by an antiphasing of precipitation between coastal Venezuela and the Venezuelan Andes (Polissar et al. 2006). The forest recovery did not seem to be influenced by the increase in precipitation ca. 140 years after the fire event. Instead, it took place during the LIA, despite decreasing regional precipitation. This fact highlights that the absence of fire may be a more important factor than regional climate in the reestablishment of the forest, and may be explained by a wetter local climate and/or the existence of a humid microclimate below the tree canopy that favoured the survival of adjacent growing trees. The disappearance of Biophytum occurred at the beginning of the LIA, in a period of decreasing precipitation, which may indicate the overcoming of the precipitation tolerance threshold for this taxon. In addition, the fact that the minimum charcoal record coincided with a period of low precipitation between $\sim 400-180$ cal yr BP highlights that climatic conditions would not be the main factor responsible for the low fire activity, suggesting that changes in human practices may be a more influential driver. Although no archaeological remains have been found in the GS indicating the presence of humans prior to the arrival of Europeans, some palaeoecological studies have suggested that human groups with landscape management practices similar to those observed today would have been 
present in this area since at least 2000 years ago (Ballesteros et al. 2014; Montoya and Rull 2011; Montoya et al. 2011b).

The natural and/or anthropogenic causes of Lateglacial and Holocene fires are an outstanding issue in the region (Rull et al. 2015a). In the GS uplands, it has been considered that most fires recorded have been of human origin (Montoya and Rull 2011; Rull et al. 2015a) but there is no palaeoecological study reporting in situ past fires on tepui summits. Nogué et al. (2009b), documented a charcoal peak at 3.9 cal kyr BP at the top of the Eruoda-tepui (>2600 m elevation) but the absence of vegetation changes and the small size of charcoal particles $(<100 \mu \mathrm{m})$ indicated that the most probable source of the charcoal were regional fires in the surrounding GS uplands. Currently, the GS is the homeland of the Pemón indigenous culture, in which the burning of vast areas of savanna, and occasionally forests (Kingsbury 2001), is recurrent. The reasons for the extent and frequency of these fires include activities such as shifting cultivation (slashand-burn in small plots cleared inside the forest, called conucos), cooking, hunting, fishing, prevention of large fires, communication, magic, etc. (Bilbao et al. 2010; Rodríguez 2004, 2007). Indeed, fire has been recognized as keystone ecological factor in the shaping of the GS vegetation since the Lateglacial, especially in the last 2000 years, when fire frequency abruptly increased (Montoya et al. 2009, 2011a,b,c; Rull 1999). The anthropogenic nature of this high fire activity was postulated based on the available palaeoclimatic and palaeoecological evidence (Montoya and Rull 2011; Rull et al. 2015a).

On the summit of Uei-tepui, the replacement of the Bonnetia forest and non-gramineous meadows by an open landscape almost totally dominated by Cyrilla was related here with the occurrence of local fires, some of them of high virulence, from the 18th century onwards. Unfortunately, a joint interpretation of these vegetation changes with the regional precipitation inferred from Cariaco is not possible due to the incompleteness of the Ti record from AD 1840 to the present. However, the occurrence of wetter climatic conditions after the LIA, coinciding with the increase in local fires, suggests that climate alone was not responsible for the vegetation shifts recorded. In addition, this period coincided with the first real penetration of Pemón territory by outsiders coming with the Spanish-Portuguese boundary commission by AD 1750 (Thomas 1982) (Fig. 6). Several missions were founded at the GS starting at AD 1770, in which most Pemón people worked and lived (Thomas 1982). The contact with this European culture led to 
a shift from nomadic to sedentary communities and to uncontrolled population growth. These social changes altered the Pemón life-style, which finally resulted in unsustainable fire practices (e.g., more intensive land use through the abbreviation of the fallow period and the location of fields more closely together, or setting fires during the dry season, which may potentially result in large, catastrophic fires) (Dezzeo et al. 2004; Kingsbury 2001, 2003; Rodríguez 2007).

Concerning the geographic origin of the local Uei-tepui fires, the probability of these fires being set at the Uei-tepui summit itself is unlikely, since the Pemón do not visit tepui summits. The possibility of the fire propagated to the Uei summit from the surrounding uplands is supported by historical observations of similar events. For example, Holdridge (1933) and Tate $(1930,1932)$ reported a fire originated in the lower slopes of Roraima on April AD 1926 during the expedition of the first, who was accompanied in his ascension by both Arekuna (a Pemón sub-group) and Patamona (indigenous group from Guyana, living in the forests) people. The fire was set accidentally at the end of an unusually dry season, which probably facilitated its propagation both to the GS uplands and the higher slopes of this tepui. The flames even reached the plateau by way of the ledge leading to the summit, although they made no progress into the vegetation there due to the abundant bare rock that characterize this particular tepui summit. Mayr and Phelps (1967) reported the evidence of fires occurred around 40 years before their expedition in AD 1966 (AD 1920s, probably contemporary to the above mentioned Roraima fire), which profoundly affected the vegetation of several eastern tepuis (Roraima, Uei, Sororopán, Auyán, Upuigma). This period coincides with the highest local fire activity recorded in Uei-tepui, and with the most recent age interval for the burnt tree trunk (24-2 cal yr BP, AD 1926-1948). Therefore, currently available data suggests that the last fire event on the Uei-tepui summit probably took place in the AD 1920s, about 90 years ago, and caused the largest effects on vegetation of the last 2000 years. The possibility of dating tree rings of known age and use them to adjust the radiocarbon calibration curve of the burnt samples may be explored in order to improve the dating of fire events within this period of time (around $165{ }^{14} \mathrm{C}$ yr BP), where precise calibrated ages are generally difficult to obtain (Maarten Blaauw, pers. comm.). However, its application in the GH may not be straightforward, given the difficulty reported by Worbes (1999) in recognizing the rings of most GS tree species. In this study, historical evidences combined with radiocarbon dating have 
resulted useful to suggest possible and most likely age intervals for the last fire event in the Uei-tepui summit, on the understanding that future advances on radiocarbon dating methods may improve the reliability of the outcome.

According to Huber (1988), only $20 \%$ of the tepui summits are totally isolated, whereas the others are connected to the surrounding lowlands/uplands, either by fully vegetated ridges, extensive valleys or gentle slopes. The reports of Tate $(1930,1932)$ of a fire event ascending the ledge and reaching the Roraima summit, which has been considered a well-isolated summit, highlights that even in table-like tepuis, fire only need a narrow continuous vegetation strip to propagate. Therefore, the potential fire disturbance would not be restricted to tepuis showing gradual slopes, but also to mostly table-like tepuis with smaller but continuous vegetated areas in the cliffs. The results of this study emphasize that tepuis located within the GS uplands are susceptible to major vegetation changes as a consequence of human-made uncontrolled fires from the GS. In the last centuries, fire has indeed become an important ecological feature that has moulded the vegetation at Uei-tepui. In order to deepen the knowledge of the ecological effects of fire in the GH, further studies should include the analysis of the remaining samples of the same core (PATAM8 A07) going back to $6000 \mathrm{cal} \mathrm{yr} \mathrm{BP,} \mathrm{and} \mathrm{the} \mathrm{extension} \mathrm{of}$ palaeoecological studies to other GH localities potentially affected by fires. Moreover, it would be beneficial to obtain independent climatic proxies from the sampling location from which palynological and charcoal analyses are conducted, in order to carry out more accurate climatic interpretations of the palaeoecological records.

\section{- Implications for conservation}

The record of vegetation changes on the summit of the Uei-tepui documented in this study and their relationship with climatic and anthropic drivers may have relevant implications for conservation. For example, the significant time lag existing between the decrease of fire incidence occurred after the charcoal peak at $\sim 810$ cal yr BP and the reestablishment of the forest, around $400 \mathrm{cal} \mathrm{yr} \mathrm{BP,} \mathrm{showed} \mathrm{that} \mathrm{the} \mathrm{recovery} \mathrm{of}$ vegetation after fire proceeded at centennial scale. A possible cause for this slow recovery process may be the highly oligotrophic environment (Huber 1995b), which determines a very low resilience of the high-tepui vegetation. However, the response of Cyrilla to fire was faster, which suggests that not only environmental factors but also individual autecological features may be involved, as for example lifespan, growth 
rates, competitive ability, etc. This highlights that understanding of individual ecological differences among species is essential in determining vegetation responses to natural or anthropogenic disturbances. Under future climate change scenarios, the interplay between environmental drivers and autecological features will be crucial in shaping the future floristic composition and the corresponding ecological communities on the summit of Uei-tepui. Another important consideration for conservation is that a highly uneven distribution of abundances among the pollen taxa included in the pollen sum can be observed in the samples of the mid-late 20th century, when Cyrilla dominated the pollen assemblages at the expense of forest and herbaceous species. This involved a substantial decrease in the ecological diversity of the vegetation atop Ueitepui during this period, which may have implications on the functioning of the entire ecosystem (Isbell et al. 2011 and literature therein).

The Intergovernmental Panel on Climate Change (IPCC 2013) projected an increase of 1 to $7^{\circ} \mathrm{C}$ in mean annual temperatures for the whole Pantepui region (including the lowlands and uplands surrounding the tepuis), whereas the projected total annual precipitation varies between $+10 \%$ and $-50 \%$ of present-day values. Although uncertainties are still important, these projections point towards a warmer and likely drier climate by 2100 , which may reduce the available moisture and potentially increase the flammability of vegetation. Under these circumstances, if fire practices in the GS remain similar to the trend observed in the last two millennia (Montoya and Rull 2011), it is likely that an increasing number of fires will reach the tepui summits. In addition, a large number of high-tepui species may be at risk due to potential habitat loss caused by upward migration following future temperature increase (Nogué et al. 2009a; Rull and Vegas-Vilarrúbia 2006; Safont et al. 2012). So far, palaeoecological evidence suggested that this risk may be overestimated, as only sensitive species would be able to migrate following climatic shifts, whereas others would be able to accommodate these changes within their ecological envelope, likely due to their phenotypic plasticity (Rull et al. 2015b; Vegas-Vilarrúbia et al. 2011). Also, their persistence in potential refugia (VegasVilarrúbia et al. 2012) or microrefugia (sensu Rull 2009), or rapid genetic adaptation should not be dismissed without positive evidence (Vegas-Vilarrúbia et al. 2011). However, future potential synergies between ongoing climate change and fire in the GH could produce non-linear ecological responses, including threshold crossing and/or 
irreversibility, which may significantly change the diversity and composition of their unique communities (Rull et al. 2013).

Currently the GH are protected by six National Parks, of which Canaima is a Natural World Heritage Site (Huber and Foster 2003), 21 Natural Monuments, and one Biosphere Reserve (Huber 1995b). Still, management plans for most of these protected areas are lacking or are insufficiently staffed (Bevilacqua et al. 2002, 2009; Castillo 2005; Huber 1995b; Novo and Díaz 2007). In addition, fire suppression actions undertaken by the Venezuelan hydro-electric company (CVG-EDELCA 2004) were seen by the Pemón populations as a threat to their culture and therefore were not well received (Rodríguez 2004, 2007). These actions followed the economic interests of the company, mainly focused on gallery forests of the GS close to the exploited river courses. In order to reduce the fire risk on tepui summits, an effective management plan with the positive interaction of local communities should be implemented in the GS, including the necessary staff to monitor the compliance of the established regulations. Besides, given the fragility of the tepui vegetation, tourist excursions as well as expeditions mobilizing large numbers of people should be limited and subjected to regulations. Campfires have been reported, though very rarely, on tepui summits (Huber 1995b; Desafío Vertical 2011, http://www.cuatro.com/desafio-vertical/, both on Auyántepui), and should be prohibited because of the risk of the fire escaping to the surrounding vegetation. Overall, a greater effort should be made in the short term by all stakeholders (land managers, indigenous communities, and tourists) to preserve the high-tepui biome before extended significant damage occurs.

\section{CONCLUSIONS}

The palynological analysis of a late Holocene sequence from the summit of Uei-tepui documented the occurrence of significant vegetation changes and the potential natural and anthropogenic drivers involved. Before $\sim 810 \mathrm{cal}$ yr BP (AD 1140), the landscape was dominated by broad-leaved non-gramineous meadows with some interspersed woody elements, mainly Biophytum, along with patches of Bonnetia cloud forest. At $\sim 810$ cal yr BP, a peak of fire incidence, coeval with a decrease in regional precipitation, took place reducing the woody elements and the cloud forests of the summit and allowing herbaceous taxa to expand. Forest recovery to its previous 
abundance occurred slowly elapsing several centuries to be completed. In contrast, Biophytum did not recover and remained virtually absent after the fire. Since the mid18th century, forests and meadows were replaced by monotypic shrublands of Cyrilla racemiflora, coinciding with intense fires, synchronous with the arrival of Europeans to the GS area by AD 1750. One of the charred tree trunks currently widespread on the Uei summit was dated to 220-168 cal yr BP (AD 1730-1782) as the most probable age interval resulting from calibration. However, the documentation of large fires in the GS tepuis (Mayr and Phelps 1967; Tate 1930, 1932), including Uei, by AD 1920s, coinciding with the second most probable age interval for the burnt tree (24-2 cal yr BP, AD 1926-1948), and especially the presence of type-III charcoal particles in the record (indicative of high virulence local fire events), suggest that this may be a likely age for the latest fire event leading to forest clearing and the establishment of present-day vegetation. Late Holocene fires documented atop Uei-tepui were most likely caused by human activities and reached the summit from the GS uplands, probably favoured by local climatic conditions. Our results suggest that fire has been the main factor in the shaping of Uei-tepui vegetation and its changes during the last two millennia, a situation that contrasts markedly with most of the tepui summits, not only of the ETC but also in the GH in general. During the last centuries, fire contributed significantly to the impoverishment of plant diversity atop Uei-tepui, a situation that could be extended to other tepui summits under the current fire management practices (Rull et al. 2013). Effective management plans should be implemented to reduce fire risk in the $\mathrm{GH}$, and with more urgency that ever, given the projected warming scenario of the area (IPCC 2013).

\section{ACKNOWLEDGEMENTS}

This research was supported by projects BIOCON 2004 90/05, BIOCON 08-188/09 (BBVA Foundation, Spain), CGL2006-00974/BOS (Ministry of Education and Science, Spain) and CGL2009-07069/BOS (Ministry of Science and Innovation, Spain) to V. Rull, and a predoctoral grant to E. Safont from the University of Barcelona. Fieldwork permits were provided by the Ministry of Science and Technology of Venezuela $\left(\mathrm{n}^{\circ}\right.$. 0000013, 5 Jan 2007) and the Ministry of Environment of the same country ( $n^{\circ}$. IE-085, 9 Feb 2007). The expedition greatly benefited from the experience and expertise of the 
helicopter pilot, Pedro Semidey, and his assistant, Fernando Hernández. We are also grateful to Sandra Nogué for her help in the field, and to Sandra Garcés and Maarten Blaauw for their contribution and valuable comments on the age-depth model and the dating of the burnt wood. The authors acknowledge the comments of two referees (Henry Hooghiemstra and anonymous), who contributed to the improvement of the original manuscript.

\section{REFERENCES}

Ballesteros T, Vegas-Vilarrúbia T, Montoya E, Abbott MB, Giralt S, Stansell N, Rull V (2014) An 8700-year record of the interplay of environmental and human drivers in the development of the southern Gran Sabana landscape, SE Venezuela. The Holocene 24:1757-1770

Bauermann SG, Radaeski JN, Evaldt ACP, Pereira Queiroz E, Mourelle D, Prieto AR, da Silva CI (2013) Pólen nas angiospermas: diversidade e evolução. Universidade Luterana do Brasil, Canoas, Brazil

Bennett KD (1996) Determination of the number of zones in a biostratigraphical sequence. New Phytol 132:155-170

Bennett KD, Willis KJ (2001) Pollen. In: Last WM, Smol JP (eds) Tracking Environmental Change using Lake Sediments, Vol 3, Terrestrial, Algal, and Siliceous Indicators. Kluwer, Dordrecht, pp 5-32

Bevilacqua M, Cárdenas L, Flores AL, Hernández L, Lares E, Mansutti A, Miranda M, Ochoa J, Rodríguez M, Selig E (2002) The State of Venezuela's Forests. A Case Study of the Guayana Region. Global Forest Watch Report, Caracas.

Bevilacqua M, Medina DA, Cárdenas L (2009) Manejo de recursos naturales en el Parque Nacional Canaima: Desafíos institucionales para la conservación. In: Celsa Señaris J, Lew D, Lasso C (eds) Biodiversidad del Parque Nacional Canaima. Bases técnicas para la conservación de la Guayana venezolana. Fundación La Salle de Ciencias Naturales and The Nature Conservancy, Caracas, pp. 209-219. 
Bilbao BA, Leal AV, Méndez CL (2010) Indigenous use of fire and forest loss in Canaima National Park, Venezuela. Assessment of and tools for alternative strategies of fire management in Pemón indigenous lands. Hum Ecol 38:663-673

Blaauw M (2010) Methods and code for 'classical' age-modelling of radiocarbon sequences. Quat Geochronol 5:512-518

Briceño HO, Schubert C (1990) Geomorphology of the Gran Sabana, Guayana Shield, southeastern Venezuela. Geomorphology 3:125-141

Burn MJ, Mayle FE (2008) Palynological differentiation between genera of the Moraceae family and implications for Amazonian palaeoecology. Rev Palaeobot Palynol 149:187-201

Bush MB, Weng C (2006) Introducing a new (freeware) tool for palynology. J Biogeogr $34: 377-380$

Bush MB, De Oliveira PA, Colinvaux PA, Miller MC, Moreno JE (2004) Amazonian paleoecological histories: one hill, three watersheeds. Palaeogeogr Palaeocl 214:359-393

Castillo R (2005) Perfil de Área Protegida - Venezuela Parque Nacional Canaima (Sector Oriental). ParksWatch Report, Venezuela.

Chen J, Saunders SC, Crow TR, Naiman RJ, Brosofske KD, Mroz GD, Brookshire BL, Franklin JF (1999) Microclimate in Forest Ecosystem and Landscape Ecology. BioScience 49:288-297

Coladonato M (1992) Cyrilla racemiflora. In: Fire Effects Information System. U.S. Department of Agriculture, Forest Service, Rocky Mountain Research Station, Fire Sciences Laboratory (Producer). http://www.fs.fed.us/database/feis/plants/shrub/cyrrac/all.html. Accessed 26 October 2015

Colinvaux PA, De Oliveira PE, Moreno JE (1999) Amazon pollen manual and atlas. Harwood Academic Publishers, Amsterdam 
Contreras-Duarte AR, Bogotá-Ángel RG, Jiménez-Bulla LC (2006) Atlas de las

Esporas de Pteridófitos de Chipaque (Cundinamarca, Colombia). Caldasia 2:327357

CVG-EDELCA (2004) La cuenca del río Caroní. Una visión en cifras. CVG-EDELCA, Puerto Ordaz, Venezuela

Dezzeo N, Fölster H, Hernández L (2004b) El fuego en la Gran Sabana. Interciencia 29:409-410

Duever MJ, Riopelle LA (1983) Successional sequences and rates on tree islands in the Okefenokee Swamp. Am Midl Nat 110:186-191

Ewel KC (1990) Swamps. In: Myers RL, Ewel JJ (eds) Ecosystems of Florida. University of Central Florida Press, Orlando, pp 281-323

Flantua SGA, Hooghiemstra H, Grimm EC, Behling H, Bush MB, González-Arango C, Gosling WD, Ledru MP, Lozano-García S, Maldonado A, Prieto AR, Rull V, Van Boxel JH (2015) Updated site compilation of the Latin American Pollen Database: challenging new research. Rev Palaeobot Palynol 223:104-115. doi:10.1016/j.revpalbo.2015.09.008

Flantua SGA, Hooghiemstra H, Vuille M, Behling H, Carson JF, Gosling WD, Hoyos I, Ledru M-P, Montoya E, Mayle F, Maldonado A, Rull V, Tonello MS, Whitney BS, González-Arango C (2016) Climate variability and human impact in South America during the last 2000 years: synthesis and perspectives from pollen records. Clim Past 12:483-523

Gorzula S, Huber O (1992) Consideraciones finales. In: Huber O (ed) El Macizo del Chimanta: Un ensayo ecológico tepuyano. Oscar Todtmann Editores, Caracas, pp 325-330

Gosling WD, Mayle FE, Tate NJ, Killeen TJ (2009) Differentiation between neotropical rainforest, dry forest, and savanna ecosystems by their modern pollen spectra and implications for their fossil pollen record. Rev Palaeobot Palynol 153:70-85

Hastenrath S, Greishar L (1993) Circulation mechanisms related to northeast Brazil rainfall anomalies. J Geophys Res 98:5093-5102 
Haug GH, Hughen KA, Peterson LC, Sigman DM, Röhl U (2001) Southward migration of the Intertropical Convergence Zone through the Holocene. Science 293:13041308

Herrera LF, Urrego LE (1996) Atlas de polen de plantas útiles y cultivadas de la Amazonia colombiana. Estudios en la Amazonia colombiana XI, Tropenbos Colombia, Bogotá, Colombia

Holdridge D (1933) Pindorama, Jungle - to you! Minton, Balch, New York.

Huber O (1988) Guayana highlands versus Guayana lowlands: a reappraisal. Taxon 37:595-614

Huber O (1992a) La vegetación. In: Huber O (ed) El Macizo del Chimantá: Un ensayo ecológico tepuyano. Oscar Todtmann Editores, Caracas, pp 161-178

Huber O (1992b) La flora: Helechos y plantas fanerógamas. In: Huber O (ed) El Macizo del Chimantá: Un ensayo ecológico tepuyano. Oscar Todtmann Editores, Caracas, pp 139-160

Huber O (1995a) Geographical and physical features. In: Berry PE, Holst BK, Yatskievych K (eds) Flora of the Venezuelan Guayana, Vol 1, Introduction. Missouri Botanical Garden Press, St. Louis, pp 1-61

Huber O (1995b) Conservation of the Venezuelan Guayana. In: Berry PE, Holst BK, Yatskievych K (eds) Flora of the Venezuelan Guayana, Vol 1, Introduction. Missouri Botanical Garden Press, St. Louis, pp 193-218

Huber O (1995c) Vegetation. In: Berry PE, Holst BK, Yatskievych K (eds) Flora of the Venezuelan Guayana, Vol 1, Introduction. Missouri Botanical Garden Press, St. Louis, pp 97-160

Huber O, Foster MN (2003) Conservation priorities for the Guayana Shield. 2002 Consensus. Conservation International, Washington.

IPCC (2013) Climate Change 2013: The Physical Science Basis. Contribution of Working Group I to the Fifth Assessment Report of the Intergovernmental Panel on Climate Change, Cambridge University Press, Cambridge 
Isbell F, Calcagno V, Hector A, Connolly J, Stanley Harpole W, Reich PB, SchererLorenzen M, Schmid B, Tilman D, van Ruijven J, Weigelt A, Wilsey BJ, Zavaleta ES, Loreau M (2011) High plant diversity is needed to maintain ecosystem services. Nature 477:199-202

Jowsey PC (1966) An improved peat sampler. New Phytol 65:245-248

Kingsbury ND (2001) Impacts of land use and cultural change in a fragile environment: indigenous acculturation and deforestation in Kavanayén, Gran Sabana, Venezuela. Interciencia 26:327-336

Kingsbury ND (2003) Same forest, different countries: cultural dimensions of protected area management in southeastern Venezuela and western Guyana. J Sustain Forest $17: 171-188$

Kologiski RL (1977) The phytosociology of the Green Swamp, North Carolina. North Carolina Agricultural Experiment Station, Raleigh, USA

Leal A, Berrío JC, Raimúndez E, Bilbao B (2011) A pollen atlas of premontane woody and herbaceous communities from the upland savannas of Guayana, Venezuela. Palynology 35:226-266

Legendre P, Legendre L (2012) Numerical ecology. Dev Environ Model 24. Amsterdam and Oxford

López-Martínez C, Lara A, Rull V, Campbell L, Nogué S (2010) Additions to the Pantepui pollen flora (Venezuelan Guayana): the Maguire collection. Collect Bot 29:31-49

Marchant R, Almeida L, Behling H, Berrío JC, Bush M, Cleef A, Duivenvoorden J, Kappelle M, De Oliveira P, Teixeira A, Lozano S, Hooghiemstra H, Ledru MP, Ludlow-Wiechers B, Markgraf V, Mancini V, Páez M, Prieto A, Rangel O, Salgado-Labouriau ML (2002) Distribution and ecology of parent taxa of pollen lodged within the Latin American Pollen Database. Rev Palaeobot Palynol 121:175

Mayr E, Phelps Jr. WH (1967) The origin of the bird fauna of the South Venezuelan Highlands. B Am Mus Nat Hist 136:269-328 
Montoya E, Rull V (2011) Gran Sabana fires (SE Venezuela): a paleoecological perspective. Quat Sci Rev 30:3430-3444

Montoya E, Rull V, Nogué S, Díaz W (2009) Paleoecología del Holoceno en la Gran Sabana, SE Venezuela: Análisis preliminar de polen y microcarbones en la Laguna Encantada. Collect Bot 28:65-79

Montoya E, Rull V, Stansell ND, Bird BW, Nogué S, Vegas-Vilarrúbia T, Abbott MB, Díaz WA (2011a) Vegetation changes in the neotropical Gran Sabana (Venezuela) around the Younger Dryas Chron. J Quat Sci 26:207-218

Montoya E, Rull V, Stansell ND, Abbott MB, Nogué S, Bird BW, Díaz WA (2011b) Forest-savanna-morichal dynamics in relation to fire and human occupation in the southern Gran Sabana (SE Venezuela) during the last millennia. Quat Res 76:335344

Montoya E, Rull V, Nogué S (2011c) Early human occupation and land use changes near the boundary of the Orinoco and the Amazon basins (SE Venezuela): palynological evidence from El Paují record. Palaeogeogr Palaeocl 310:413-426

Murillo MT, Bless MJM (1974) Spores of Recent Colombian Pteridophyta. I. Trilete Spores. Rev Palaeobot Palynol 18:223-269

Murillo MT, Bless MJM (1978) Spores of Recent Colombian Pteridophyta. II. Monolete Spores. Rev Palaeobot Palynol 25:319-365

Nogué S, Rull V, Vegas-Vilarrúbia T (2009a) Modeling biodiversity loss by global warming on Pantepui, northern South America: projected upward migration and potential habitat loss. Climatic Change 94:77-85

Nogué S, Rull V, Montoya E, Huber O, Vegas-Vilarrúbia T (2009b) Palaeoecology of the Guayana Highlands (northern South America): Holocene pollen record from the Eruoda-tepui, in the Chimantá massif. Palaeogeogr Palaeocl 281:165-173

Novo I, Díaz D (2007) Informe Final de la Evaluación del Parque Nacional Canaima, Venezuela, como Sitio de Patrimonio Natural de la Humanidad. Inparques and Vitalis, Caracas, Venezuela 
Polissar PJ, Abbott MB, Wolfe AP, Bezada M, Rull V, Bradley RS (2006) Solar modulation of Little Ice Age climate in the tropical Andes. Proc Natl Acad Sci USA 103:8937-8942

Reimer PJ, Bard E, Bayliss A et al (2013) INTCAL13 and MARINE13 radiocarbon age calibration curves, 0-50,000 years cal BP. Radiocarbon 55:1869-1887

Renssen H, Seppä H, Heiri O, Roche DM, Goosse H, Fichefet T (2009) The spatial and temporal complexity of the Holocene thermal maximum. Nature Geosci 2: 411-414

Robertson K, Harper MG, Woolery M (1998) Management of Peatland Shrub- and Forest-dominated Communities for Threatened and Endangered Species. USACERL Technical Report 99/08, Champaign

Rodríguez I (2004) Conocimiento indígena vs científico: el conflicto por el uso del fuego en el Parque Nacional de Canaima, Venezuela. Interciencia 29:121-129

Rodríguez I (2007) Pemon Perspectives of fire management in Canaima National Park, southeastern Venezuela. Hum Ecol 35:331-343

Roubik DW, Moreno JE (1991) Pollen and spores of Barro Colorado Island.

Monographs in Systematic Botany, 36. Missouri Botanical Garden Press, St. Louis, USA

Rull V (1987) A note on pollen counting in palaeoecology. Pollen Spores 29:471-480

Rull V (1998) Contribuciones a la morfología polínica de las Urticales de los Andes

Venezolanos. Acta Botánica Venezuelica, 21:43-73

Rull V (1999) A palynological record of a secondary succession after fire in the Gran Sabana, Venezuela. J Quat Sci 14:137-152

Rull V (2003) An illustrated key for the identification of pollen from Pantepui and the Gran Sabana (eastern Venezuelan Guayana). Palynology 27:99-133

Rull V (2004a) An evaluation of the lost world and the vertical displacement hypotheses in the Chimantá massif, Venezuelan Guayana. Global Ecol Biogeogr 13:141-148

Rull V (2004b) Is the 'Lost World' really lost? Palaeoecological insights into the origin of the peculiar flora of the Guayana Highlands. Naturwissenschaften 91:139-142 
Rull V (2004c) Biogeography of the "Lost World": a paleoecological perspective. Earth-Sci Rev 67:125-137

Rull V (2005a) Vegetation and environmental constancy in the Neotropical Guayana Highlands during the last 6000 years? Rev Palaeobot Palynol 135:205-222

Rull V (2005b) Palaeovegetational and palaeoenvironmental trends in the summit of the Guaiquinima massif (Venezuelan Guayana) during the Holocene. J Quat Sci 20:135-145

Rull V (2007) Holocene global warming and the origin of the neotropical Gran Sabana in the Venezuelan Guayana. J Biogeogr 34:279-288

Rull V (2009) Microrefugia. J Biogeogr 36:481-484

Rull V (2010) The Guayana Highlands: a natural laboratory for the biogeographical and evolutionary study of the neotropical flora. In: Sánchez-Villagra M, Aguilera O, Carlini A (eds) Urumaco and Venezuelan palaeontology-the fossil record of the northern Neotropics. Indiana University Press, Indiana, USA, pp 84-102

Rull V (2015) Long-term vegetation stability and the concept of potential natural vegetation in the Neotropics. J Veg Sci 26:603-607

Rull V, Vegas-Vilarrúbia T (2006) Unexpected biodiversity loss under global warming in the neotropical Guayana Highlands. Global Change Biol 12:1-9

Rull V, Montoya E (2014) Mauritia flexuosa palm swamp communities: natural or human-made? A palynological study of the Gran Sabana region (northern South America) within a neotropical context. Quat Sci Rev 99:17-33

Rull V, Montoya E, Nogué S, Huber O (2011) Preliminary palynological analysis of a Holocene peat bog from Apakará-tepui (Chimantá-Massif, Venezuelan Guayana). Collect Bot 30:79-88

Rull V, Montoya E, Nogué S, Vegas-Vilarrúbia T, Safont E (2013) Ecological paleoecology in the neotropical Gran Sabana region, long-term records of vegetation dynamics as a basis for ecological hypothesis testing. Perspect Plant Ecol Evol Syst 15:338-359 
Rull V, Montoya E, Vegas-Vilarrúbia T, Ballesteros T (2015a) New insights on palaeofires and savannisation in northern South America. Quat Sci Rev 122:158165

Rull V, Vegas-Vilarrúbia T, Montoya E (2015b) Neotropical vegetation responses to Younger Dryas climates as analogs for future climate change scenarios and lessons for conservation. Quat Sci Rev 115:28-38

Safont E, Vegas-Vilarrúbia T, Rull V (2012) Use of Environmental Impact Assessment (EIA) tools to set priorities and optimize strategies in biodiversity conservation. Biol Conserv 149:113-121

Safont E, Rull V, Vegas-Vilarrúbia T, Holst BK, Huber O, Nozawa S, Vivas Y, Silva A (2014) Establishing a baseline of plant diversity and endemism on a neotropical mountain summit for future comparative studies assessing upward migration: an approach from biogeography and nature conservation. Syst Biodivers 12:292-314

Salgado-Labouriau ML, Villar L (1992) Contribución a la flora polínica de los tepuyes. In: Huber O (ed) El Macizo del Chimantá: Un ensayo ecológico tepuyano. Oscar Todtmann Editores, Caracas, pp 219-236

Schubert C, Fritz P (1985) Radiocarbon ages of peat, Guayana Highlands (Venezuela). Naturwissenschaften 72:427-429

Schubert C, Briceño HO, Fritz P (1986) Paleoenvironmental aspects of the CaroníParagua river basin (southeastern Venezuela). Interciencia 11:278-289

Steyermark JA, Berry PE, Holst BK (1995-2005) Flora of the Venezuelan Guayana. Missouri Botanical Garden Press, St. Louis, USA

Tate GHH (1930) Notes on the Mount Roraima Region. Geogr Rev 20:53-68

Tate GHH (1932) Life Zones at Mount Roraima. Ecology 13:235-257

Thomas DJ (1982) Order Without Government: The Society of the Pemons Indians of Venezuela. University of Illinois Press, Illinois, USA

Tryon AF, Lugardon B (1991) Spores of Pteridophyta. Springer-Verlag, New York 
Vegas-Vilarrúbia T, Rull V, Montoya E, Safont E (2011) Quaternary palaeoecology and nature conservation: a general review with examples from the neotropics. Quat Sci Rev 30:2361-2388

Vegas-Vilarrúbia T, Nogué S, Rull V (2012) Global warming, habitat shifts and potential refugia for biodiversity conservation in the neotropical Guayana Highlands. Biol Conserv 152:159-168

Worbes M (1999) Degradación e historia de la vegetación boscosa de la Gran Sabana. Scientia Guaianae 9:84-107 


\section{Tables}

Table 1 Radiocarbon dates of Uei-tepui core (PATAM8 A07). Two-sigma confidence intervals for calibrated years are given in brackets for the highest probability intervals (RAPD). Asterisks mark the samples within the temporal interval included in this study.

\begin{tabular}{llllll}
\hline Depth $(\mathbf{c m})$ & Lab code & Sample type & ${ }^{\mathbf{1 4}} \mathbf{C}$ yr BP & $\begin{array}{l}\text { Median cal yr } \\
\text { BP (2 } \boldsymbol{\sigma})\end{array}$ & RAPD $^{\mathbf{a}}$ \\
& & & & $181(137-224)$ & 0.473 \\
\hline $40-42 *$ & Beta-247288 & Macroremains & $220 \pm 40$ & $287(256-318)$ & 0.355 \\
\hline $90-92 *$ & Beta-247289 & Macroremains & $1900 \pm 40$ & $1827(1728-1926)$ & 1.000 \\
\hline $144-146$ & Beta-247290 & Macroremains & $3800 \pm 50$ & $4199(4079-4319)$ & 0.863 \\
\hline $178-182$ & UCI-37497 & Macroremains & $5200 \pm 15$ & $5936(5918-5953)$ & 0.566 \\
& & & & $5975(5961-5989)$ & 0.434 \\
\hline Modern burnt & UCI-37500 & Macroremains & $165 \pm 15$ & $194(168-220)$ & 0.547 \\
wood* & & & & & \\
\hline
\end{tabular}

${ }^{a}$ Relative area under probability distribution (Reimer et al. 2013). 


\section{Figures}

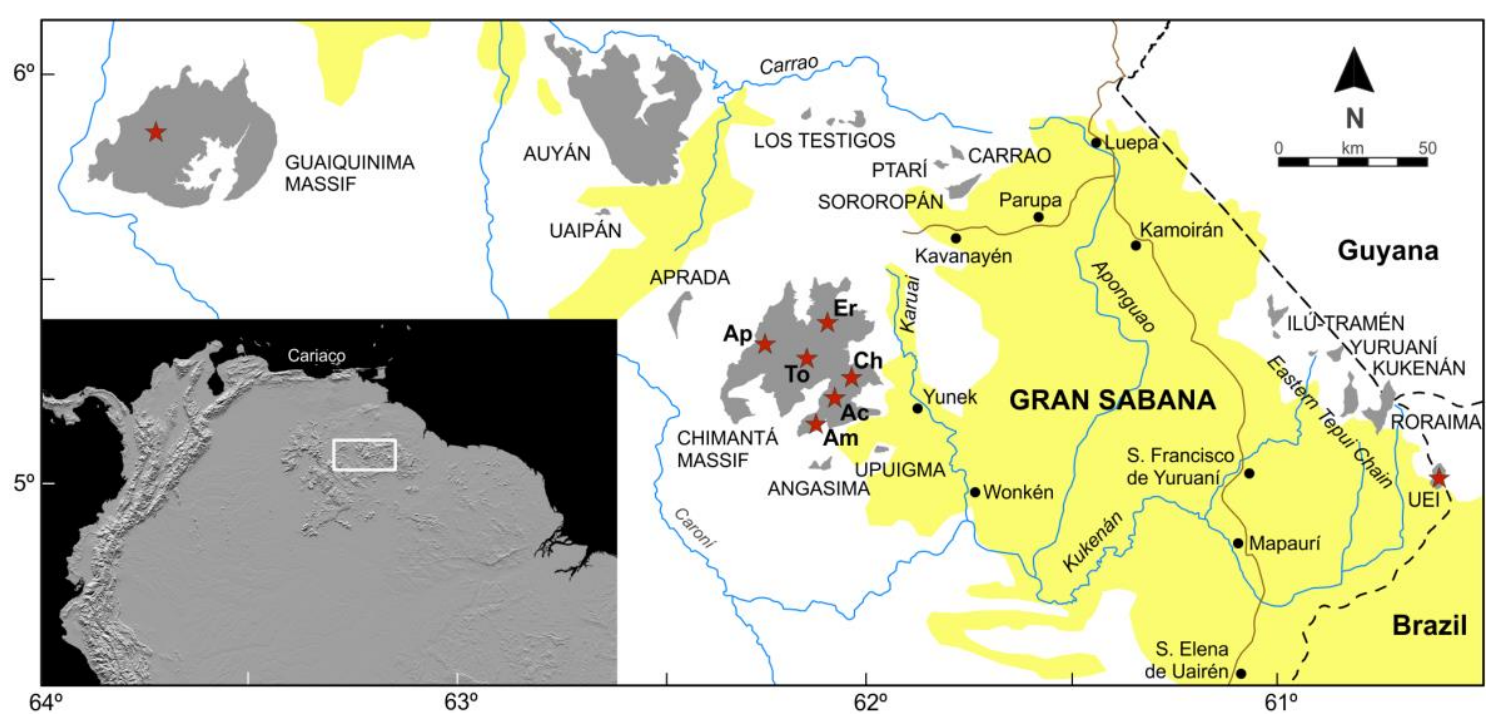

Fig. 1 Map of the study area and its location within northern South America (radar image courtesy of NASA/JPL-Caltech). Tepuis are represented with grey areas, and red stars indicate the palaeo-records obtained from tepui summits. In the Chimantá Massif, Ac: Acopán, Am: Amurí, Ap: Apakará, Ch: Churí, Er: Eruoda, and To: Toronó. Yellow areas indicate the current presence of savannas, while rivers, roads, and political boundaries are represented by blue, brown, and dashed black lines, respectively. 

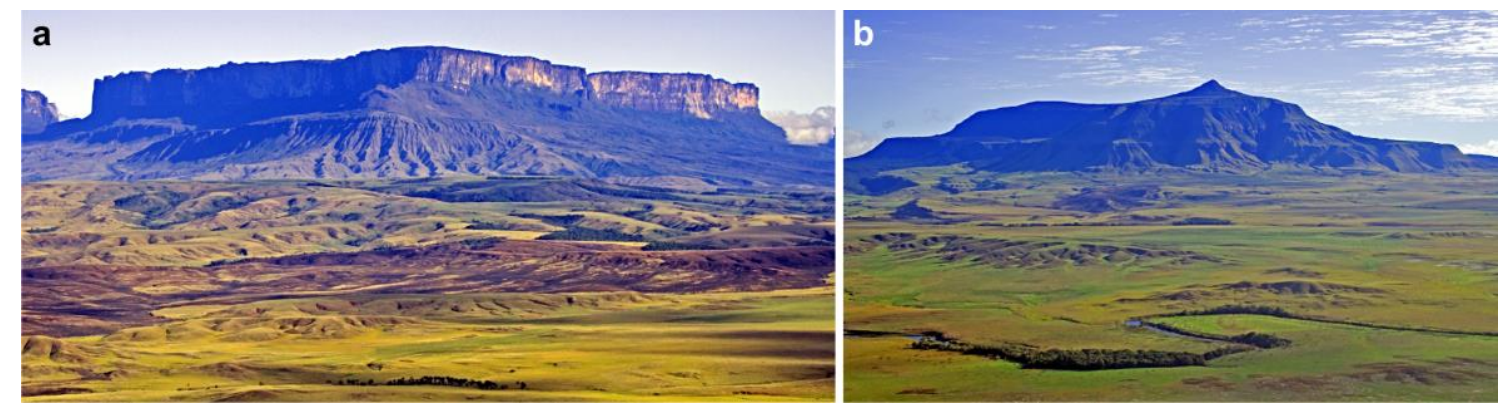

Fig. 2 Topographic differences between the Roraima-tepui (a), which flat summit is surrounded by vertical walls, and the Uei-tepui (b), with gentle slopes enabling the continuity of vegetation between the GS savannas (in the foreground) and the tepui summit (Photos V. Rull). Elevation and summit areas are $2810 \mathrm{~m}$ and $34.4 \mathrm{~km}^{2}$ for Roraima-tepui and $2150 \mathrm{~m}$ and $2.5 \mathrm{~km}^{2}$ for Ueitepui.
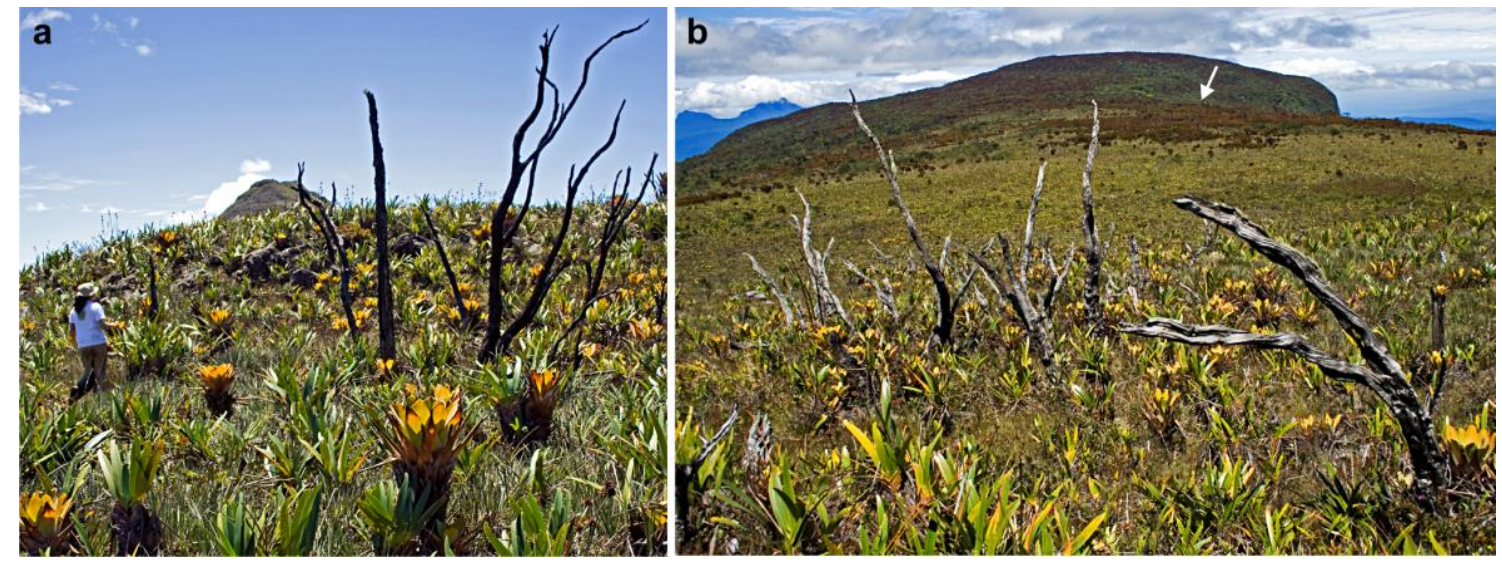

Fig. 3 Vegetation of the Uei-tepui summit near the coring site. a) View to the $S$ of the coring site showing the broad-leaved Stegolepis guianensis and the large rosettes of Brocchinia tatei, together with some standing charred trees, probably of Bonnetia sp. b) View to the N, with the dominant broad-leaved meadows and a clump of charred trees. Residual patches of Bonnetia tepuiensis forests are present in the background (white arrow) (Photos V. Rull). 


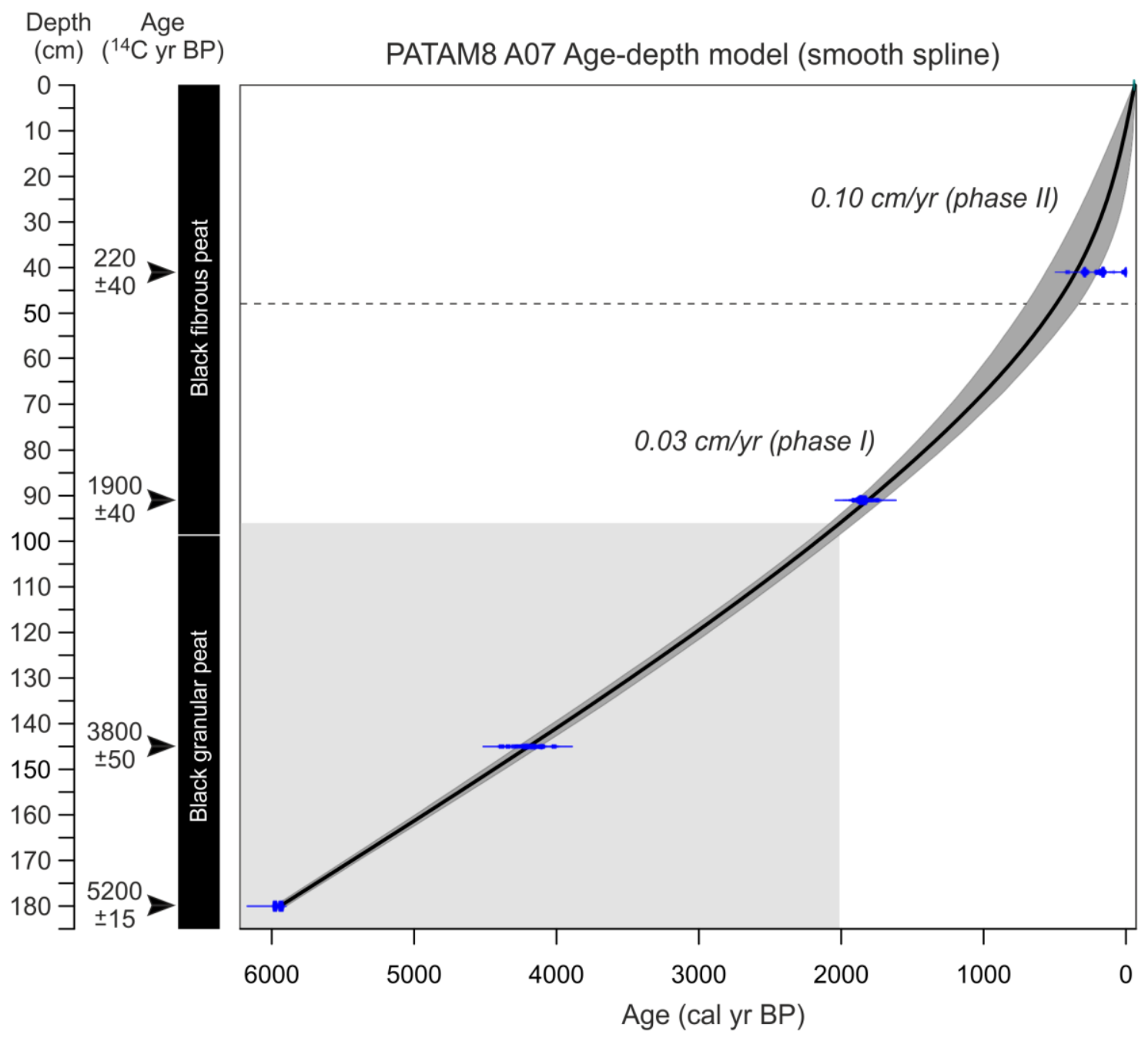

Fig. 4 Age-depth model of core PATAM8 A07, core stratigraphy with radiocarbon ages, and lithological column. The average accumulation rates of peat are indicated. The white area is that analysed in this study. 


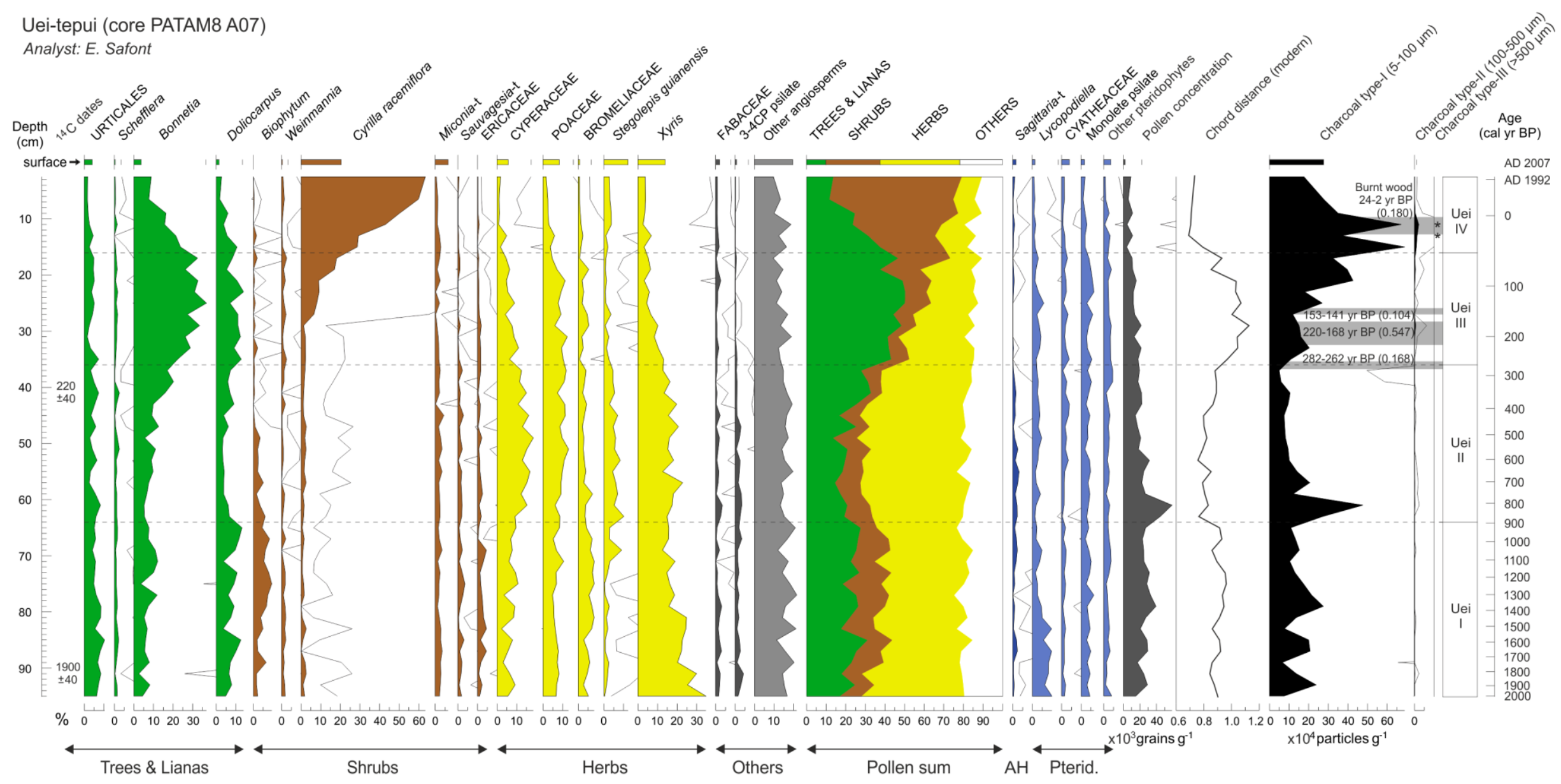

Fig. 5 Pollen percentage diagram of core PATAM8 A07. Solid lines indicate x10 exaggeration. The surface sample is represented at the top of the diagram using horizontal bars. Two-sigma confidence intervals for calibrated years of the burnt wood sample are indicated with grey areas in the charcoal section of the diagram, including the relative area under the probability distribution for each period, resulting from the age calibration. AH: aquatic herb, Pterid.: Pteridophyte spores. 


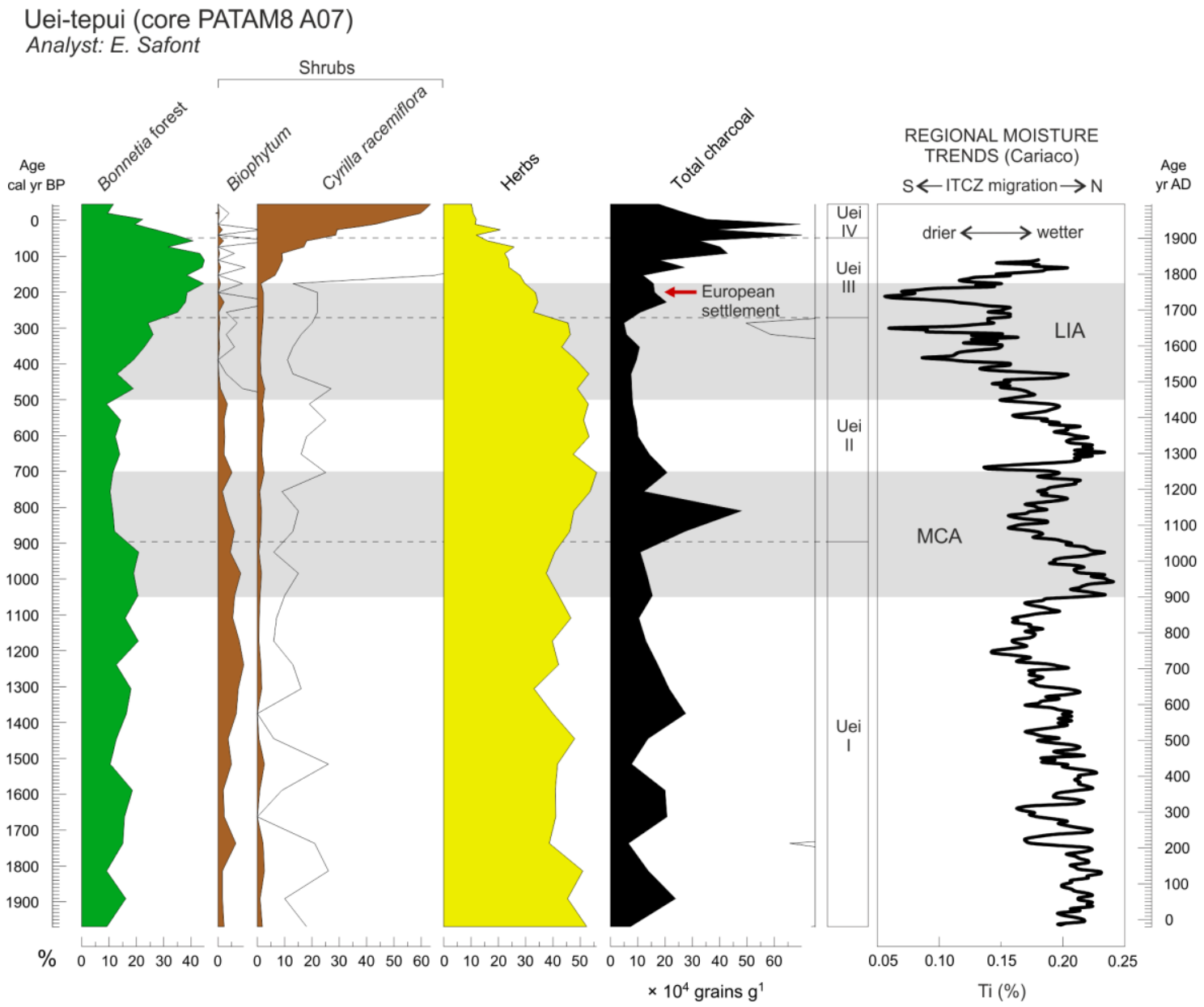

Fig. 6 Pollen percentage diagram of core PATAM8 A07 with selected taxa, charcoal concentration and the percentage of titanium from the Cariaco Basin (Haug et al. 2001), as a proxy for regional precipitation. Solid lines indicate x10 exaggeration. The Little Ice Age (LIA) and the Medieval Climatic Anomaly (MCA) (Haug et al. 2001) are represented with grey areas. 